\title{
Assessment of the effects of urbanization on trace elements of toe bones
}

\section{Edina Simon, Miklós Puky, Mihály Braun \& Béla Tóthmérész}

\section{Environmental Monitoring and} Assessment

An International Journal Devoted to Progress in the Use of Monitoring Data in Assessing Environmental Risks to Man and the Environment

ISSN 0167-6369

Volume 184

Number 9

Environ Monit Assess (2012)

184:5749-5754

DOI 10.1007/s10661-011-2378-y

\section{ENVIRONMENTAL MONITORING AND ASSESSMENT}

\begin{tabular}{lr}
\hline An International Journal devoted to progress in the use of monitoring \\
data in assessing environmental risks to Man and the environment.
\end{tabular}$\quad \begin{array}{r}\text { ISSN 0167-6369 } \\
\text { CODEN EMASDH }\end{array}$

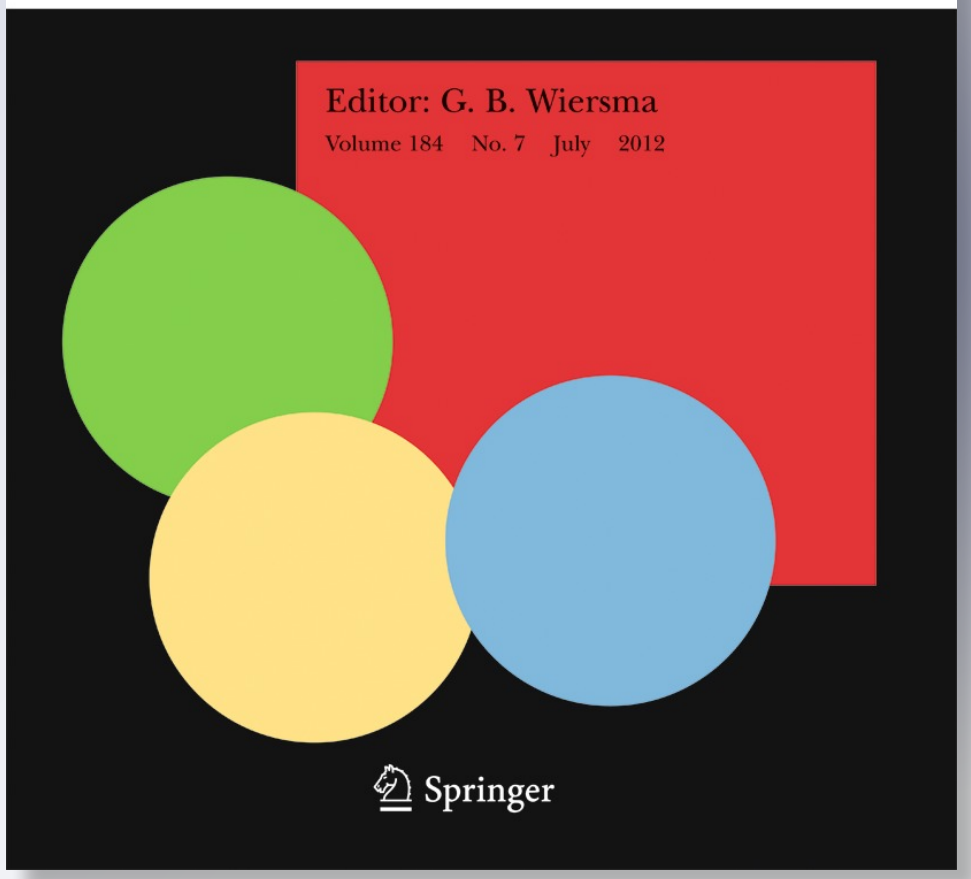

\section{自 Springer}


Your article is protected by copyright and all rights are held exclusively by Springer Science+Business Media B.V.. This e-offprint is for personal use only and shall not be selfarchived in electronic repositories. If you wish to self-archive your work, please use the accepted author's version for posting to your own website or your institution's repository. You may further deposit the accepted author's version on a funder's repository at a funder's request, provided it is not made publicly available until 12 months after publication. 


\title{
Assessment of the effects of urbanization on trace elements of toe bones
}

\author{
Edina Simon • Miklós Puky • Mihály Braun • \\ Béla Tóthmérész
}

Received: 18 November 2010 / Accepted: 16 September 2011/Published online: 1 October 2011

(C) Springer Science+Business Media B.V. 2011

\begin{abstract}
Amphibians, particularly frogs and toads, are increasingly used as bioindicators of contaminant accumulation in pollution studies. We developed an analytical technique to analyse their elemental contents based on a small amount of toe bone samples. This method is environment-friendly as, unlike traditional methods, it is not necessary to kill animals during sampling. Using this technique, we explored the effects of urbanization on the elemental contents of toe bones. Bufo bufo specimens were collected from an urban and two rural ponds. The ratios of $\mathrm{Ca}$ and $\mathrm{P}$ at the ponds were: $20.5 \% \mathrm{Ca}$ and $14.6 \% \mathrm{P}$ at the urban pond and $30.4 \%$ and $29.6 \% \mathrm{Ca}, 22.4 \%$ and $21.7 \% \mathrm{P}$ at the rural ponds, respectively. For the other elements, the following percentage ratios were found: $0.7 \% \mathrm{~B}$, $0.3 \% \mathrm{Mg}$ and $0.06 \% \mathrm{Zn}$ at the urban pond and $1.1 \%$ and $0.4 \% \mathrm{~B}, 0.4 \% \mathrm{Mg}$ and $0.05 \% \mathrm{Zn}$ at the rural
\end{abstract}

E. Simon $(\bowtie) \cdot B$. Tóthmérész

Department of Ecology, University of Debrecen,

Debrecen, P.O. Box 71, 4010 Hungary

e-mail: edina.simon@gmail.com

M. Puky

Hungarian Danube Research Institute of the Hungarian

Academy of Sciences,

Jávorka S. u. 14,

Göd 2131 Hungary

M. Braun

Department of Inorganic and Analytical Chemistry,

University of Debrecen,

Debrecen, P.O. Box 21, 4010 Hungary ponds, respectively. Canonical discriminant analysis indicated the separation of the urban and the rural ponds based on the elemental concentrations of toe bones. Significant differences were found between the concentrations of $\mathrm{Ca}, \mathrm{P}, \mathrm{Mg}, \mathrm{B}$ and $\mathrm{Zn}$ at the urban and the rural ponds $(p<0.05)$. Anthropogenic activity was found to have effects on the elemental contents of toe bones in the urbanized area. Our study also demonstrated that the developed method was appropriate for the elemental analysis of small samples to assess the effects of urbanization.

Keywords Bioindicators · ICP-OES · Bufo bufo . Ponds $\cdot$ Calcium $\cdot$ Phosphorus

\section{Introduction}

Amphibians are the main components of aquatic and terrestrial ecosystems (Unrine et al. 2007) and are an important link between human and ecosystem health (Hayes et al. 2002). Through their life cycle, they play important roles in freshwater and terrestrial habitats (Rowe et al. 2001). Since most amphibians, particularly frog and toads species, are connected to both aquatic and terrestrial habitats, they may suffer from the direct and indirect effects of environmental pollution, such as habitat loss and fragmentation (Icochea et al. 2002), ultraviolet radiation, toxic chemicals (Blaustein et al. 2003), industrial and domestic chemical contamination (Mizgireuv et al. 
1984), and parasitic infection (Johnson et al. 1999). The effects of contamination may result in shorter body length, lower body mass and malformations of limbs or other organs (Sparling et al. 2000). As a result, anurans are increasingly used as bioindicators of contaminant accumulation in pollution studies (Welsh and Ollivier 1998; Johansson et al. 2001; Loumbourdis et al. 2007).

Elemental analysis, especially that of heavy metals in amphibians, began to attract special attention (Stolyar et al. 2008). Metal accumulations and their effects were investigated both under laboratory (Perez-Coll et al. 1997; Herkovits and Helguero 1998; James and Little 2003) and field conditions (Demichellis et al. 2001; Flyaks and Borkin 2004; Fenoglio et al. 2006; Puky and Oertel 1997), but the number of field studies is low. In a preliminary study, we demonstrated that the elemental contents of bones were correctly represented by the phalanges (Simon et al. 2010). Based on those results, we intended to develop a new technique to explore the effects of urbanization on the elemental concentration of the toads' skeletal system, which can be used without killing the animals. Our hypothesis was that the concentration of trace elements in bones was higher in toads from the urban pond than those from the rural ones. We also studied whether the anthropogenic effects at the urban pond caused any morphological or developmental abnormalities in the examined specimens.

\section{Materials and methods}

Bufo bufo specimens were collected during their reproductive period from different ponds during spring, 2007. It is a common species both in Europe and Hungary. Two rural ponds-Garancsi pond at Tinnye $\left(43^{\circ} 37^{\prime} \mathrm{N}, 18^{\circ} 48^{\prime} \mathrm{E}\right)$ and Naplás pond, a reservoir on the Szilas stream with a diverse amphibian fauna $\left(47^{\circ} 30^{\prime} \mathrm{N}, 19^{\circ} 14^{\prime} \mathrm{E}\right)$ - were investigated.
The third sampling site was the Frog Pond in Debrecen, which is an urban pond in the centre of Debrecen city $\left(47^{\circ} 33^{\prime} \mathrm{N}, 21^{\circ} 37^{\prime} \mathrm{E}\right)$. Habitat characterization of the ponds is shown in Table 1 .

Adult toads $(N=11)$ were collected by dipnet at the urban pond. At the rural ponds (Garancsi pond, $N=21$; Naplás pond, $N=5$ ), toe bones were taken from road-killed specimens which died during migration. Toe clipping was made by a stainless steel surgical folding knife following Green's (2001) recommendations. The removed toes were stored in a freezer in plastic Eppendorf tubes until processing. Each toe sample was placed into a plastic sieve and flushed with $100 \mathrm{~mL}$ of double deionised water. After this step, the toes were placed into $2 \mathrm{~mL} 30 \%(\mathrm{~m} / \mathrm{m})$ hydrogen peroxide for 2 days to clean the toe bone of conjunctive tissues. After the hydrogen peroxide treatment, samples were flushed with deionised water again and then dried overnight at $105^{\circ} \mathrm{C}$. The dry weights of toe bones were measured with a SARTORIUS LE 26P micro-analytical balance. Dry toe bones were digested using $2 \mathrm{~mL} 65 \%(\mathrm{~m} / \mathrm{m})$ nitric acid at $80^{\circ} \mathrm{C}$ for $4 \mathrm{~h}$. The digested samples were diluted to $20 \mathrm{~mL}$ using $1 \%(\mathrm{~m} / \mathrm{m})$ nitric acid solution.

Element analysis was performed by ICP-OES IRIS Intrepid II XSP. We used a seven-point calibration procedure $(0.001,0.005,0.01,0.05,0.1,0.5$ and $1.0 \mathrm{mg} \mathrm{L}^{-1}$ ) with multi-elemental calibration solution (Merk ICP multi-element standard solution IV). The limit of quantification values were given in milligrams per litre (B, 0.005; $\mathrm{Ca}, 0.0082 ; \mathrm{Mg}, 0.0013 ; \mathrm{P}$, $0.0020 ; \mathrm{Zn}, 0.0034)$. The elemental content of bone samples was expressed in milligrams or micrograms per toe bone in our study.

The effects of the habitats including anthropogenic impacts on the elemental composition of $B$. bufo specimens were evaluated by canonical discriminant analysis and by ANOVA. Concentration data were $\ln$ $(x+1)$ transformed. Calculations were performed by the SPSS/PC+ software package. In the case of
Table 1 Landscape elements (in percentages) around the ponds in a plot of $1 \times 1 \mathrm{~km}$

\begin{tabular}{lccccc}
\hline Study area & Pond (\%) & Forest (\%) & Field (\%) & $\begin{array}{c}\text { Agricultural } \\
\text { area (\%) }\end{array}$ & Buildings (\%) \\
\hline Frog pond & 0.4 & 39.7 & - & - & 59.9 \\
Garancsi pond & 2 & 22.3 & 53.2 & 22.5 & - \\
Naplás pond & 14.1 & 15.3 & - & 70.6 & - \\
\hline
\end{tabular}




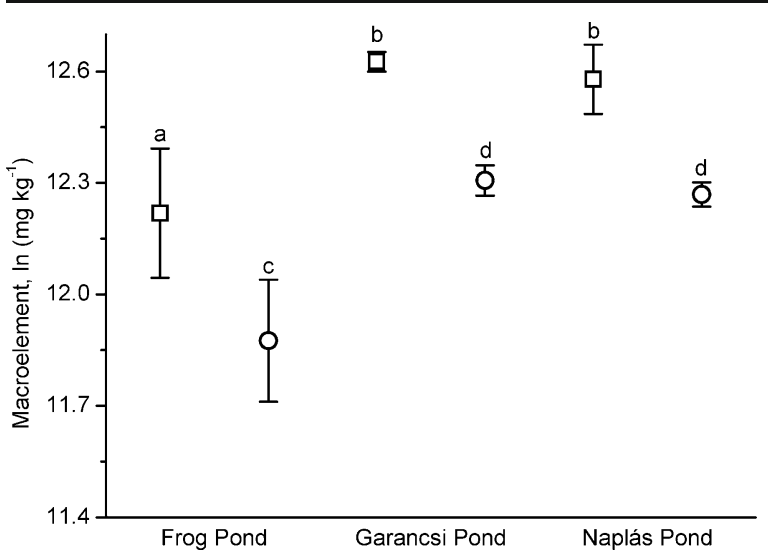

Fig. $1 \mathrm{Ca}$ and $\mathrm{P}$ concentrations (mean $\pm \mathrm{SD}$ ) of $B$. bufo toe bones at the urban (frog pond) and rural (Garancsi and Naplás ponds) ponds: Ca (open square), P (open circle). Different superscript letters indicate significant differences between the ponds

significant differences, Tukey's multiple comparison test was used (Zar 1996).

\section{Results}

Toe bone's dry weights (in milligrams, mean \pm SD) were $0.9 \pm 0.3$ from the urban pond and $0.8 \pm 0.5$ and $1.9 \pm 1.2$ from the rural ponds, respectively. $\mathrm{Ca}$ and $\mathrm{P}$ occurred in the highest concentrations in the toe bones (Fig. 1). The percentage ratios of these elements were $20.5 \% \mathrm{Ca}$ and $14.6 \% \mathrm{P}$ at the urban pond and $30.4 \%$ and $29.5 \% \mathrm{Ca}, 22.4 \%$ and $21.7 \% \mathrm{P}$ at the rural ponds,

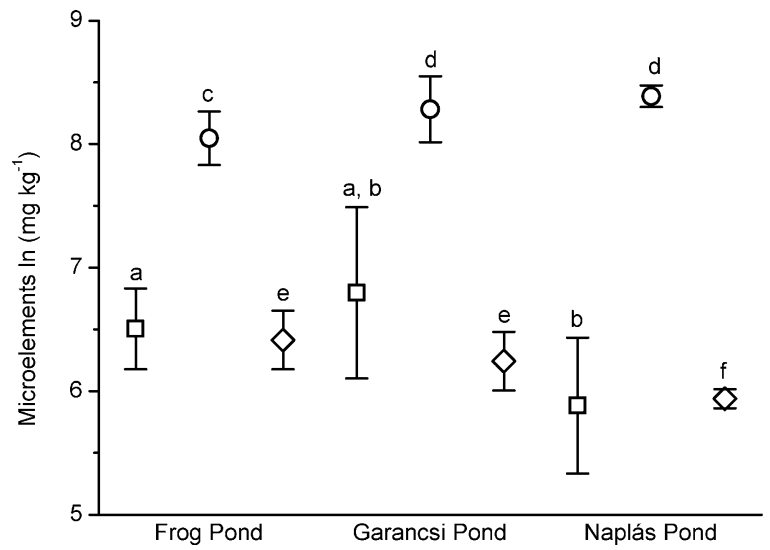

Fig. 2 Microelement concentrations (mean $\pm \mathrm{SD}$ ) of $B$. bufo toe bones at the urban (frog pond) and rural (Garancsi and Naplás ponds): $\mathrm{B}$ (open square), $\mathrm{Mg}$ (open circle), $\mathrm{Zn}$ (open diamond). Different superscript letters indicate significant differences between the ponds
Table 2 Summary of canonical discriminant functions for elemental concentrations in the toe bones of toads (micrograms per gram dry weight)

\begin{tabular}{lcc}
\hline & \multicolumn{2}{c}{ Discriminant functions } \\
\cline { 2 - 3 } & I & II \\
\hline Eigenvalue & 12.1 & 0.4 \\
Percentage of variance & 96.8 & 3.2 \\
Cumulative percentage & 96.8 & 100.0 \\
Canonical correlation & 1.0 & 0.5 \\
Wilks' lambda & 0.05 & 0.72 \\
Chi-square & 90.1 & 10.4 \\
df & 10 & 4 \\
Significance & $p<0.001$ & 0.034 \\
Elements of structure matrix & & \\
P & $\mathbf{0 . 5 9 1}$ & 0.306 \\
Ca & $\mathbf{0 . 5 3 3}$ & 0.338 \\
B & 0.020 & $\mathbf{0 . 8 6 0}$ \\
Zn & -0.144 & $\mathbf{0 . 7 1 4}$ \\
Mg & 0.146 & $-\mathbf{0 . 2 1 1}$ \\
\hline
\end{tabular}

The largest absolute correlations between each variable and any discriminant function are marked with bold letters

respectively. The micro-elemental content of toe bones is shown in Fig. 2. In the case of these elements, the percentage ratios were small: $0.7 \% \mathrm{~B}$, $0.3 \% \mathrm{Mg}$ and $0.06 \% \mathrm{Zn}$ at the urban pond and $1.1 \%$ and $0.4 \% \mathrm{~B}, 0.4 \% \mathrm{Mg}$ and $0.05 \% \mathrm{Zn}$ at the rural ponds, respectively.

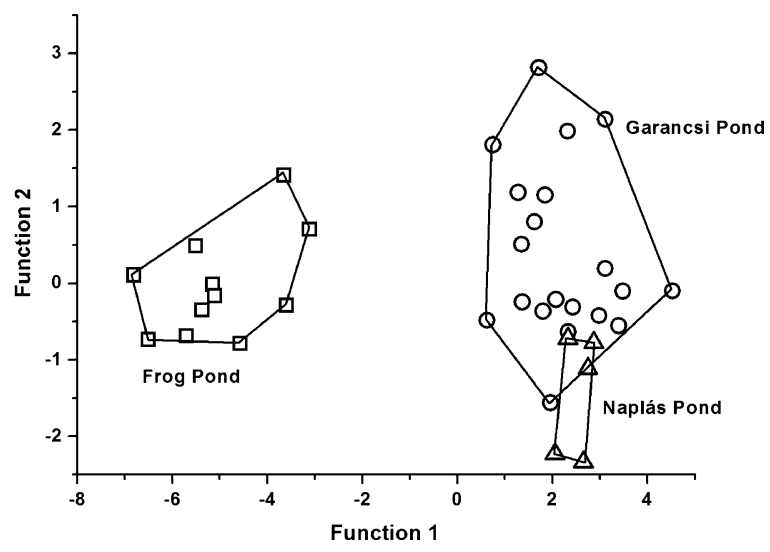

Fig. 3 Canonical discriminant analysis of the urban (frog pond) and rural (Garancsi and Naplás ponds) ponds based on the macro- and microelement concentrations in B. bufo toe bones (milligrams per kilogram dry weight) 
Canonical discriminant analysis indicated significant differences in the first $(p<0.001)$ and second $(p=0.034)$ discriminant functions based on the concentration of elements. The scatterplot of discriminant scores showed the separation of the urban and the two rural ponds based on the elemental concentrations of toe bones (Table 2). Of the samples, $86.1 \%$ was classified correctly (Fig. 3). A significant positive correlation was found between the first discriminant function and the measured elements ( $\mathrm{Ca}$ and $\mathrm{P})$. This correlation indicated that the elemental concentrations were significantly higher at the rural ponds. In the case of $\mathrm{B}$ and $\mathrm{Zn}$, the correlations were positive with the second functions, so there were smaller amounts of these elements in the toe bones from the rural ponds than the urban one. The Mg concentration was negatively correlated with the second function.

Significant differences were found between the urban and rural ponds $(p<0.05)$ in the case of all measured elements. The concentrations of $\mathrm{Ca}, \mathrm{P}$ and $\mathrm{Mg}$ were significantly higher in the toe bones from the rural ponds $(p<0.001)$; no significant differences were detected between the two rural sites in this respect $(p>0.05)$. On the other hand, the concentration of B markedly differed only between the rural ponds $(p<0.05)$. Zn concentration was the highest at the urban pond, which significantly differed from only one of the rural ponds $(p<0.05)$. Detailed results of the statistical analysis are shown in Table 3.

\section{Discussion}

The usual composition of bones includes 70\% minerals, $20 \%$ collagen, $8 \%$ water and about $2 \%$ non-collagenous components (Klepinger 1984). Similar to an earlier study (Oudadesse et al. 2004), our results showed $\mathrm{Ca}, \mathrm{P}$ and $\mathrm{Mg}$ to be the main elements in the bones. $\mathrm{Ca}$ and $\mathrm{P}$, the main components in hydroxyapatite, are known to be of at most importance (Janus et al. 2008). Smaller Ca and P concentrations cause smaller hydroxyapatite content in the bones. Although physiological differences were not found in the toe bones, decreasing hydroxyapatite content may cause more porous structure in the bones (Janus et al. 2008). $\mathrm{Zn}$ is one of the microelements which are retained in terrestrial metamorphosis (Unrine et al. 2007); thus, Zn may also be monitored in adult amphibians. Our results showed a significantly higher $\mathrm{Zn}$ concentration at the urban pond than at one of the rural ponds. Similar differences were also reported by Flyaks and Borkin (2004) and Stolyar et al. (2008), whilst Pavel and Kucera (1986) did not find considerable differences in $\mathrm{Zn}$ concentrations between Rana esculenta from urban and rural ponds.

The use of amphibians as biological indicators has become increasingly important to assess the quality of their environment (Rowe et al. 2001). The available analytical methods are relatively well developed, but they often require the killing of the investigated individuals. With the developed micro-analytical
Table 3 ANOVA of elemental concentrations in toe bones (milligrams per kilogram dry weight)

\begin{tabular}{|c|c|c|c|c|c|c|}
\hline \multicolumn{2}{|c|}{ Elements } & \multirow{2}{*}{$\frac{\text { Sum of squares }}{3.42}$} & \multirow{2}{*}{$\frac{d f}{2}$} & \multirow{2}{*}{$\frac{\text { Mean square }}{1.710}$} & \multirow{2}{*}{$\begin{array}{l}F \\
4.947\end{array}$} & \multirow{2}{*}{$\frac{p \text { value }}{<0.05}$} \\
\hline $\mathrm{B}$ & Between groups & & & & & \\
\hline & Within groups & 11.40 & 33 & 0.346 & & \\
\hline & Total & 14.82 & 35 & & & \\
\hline \multirow[t]{3}{*}{$\mathrm{Ca}$} & Between groups & 1.22 & 2 & 0.610 & 57.448 & $<0.001$ \\
\hline & Within groups & 0.35 & 33 & 0.011 & & \\
\hline & Total & 1.57 & 35 & & & \\
\hline \multirow[t]{3}{*}{$\mathrm{Mg}$} & Between groups & 0.55 & 2 & 0.273 & 4.829 & $<0.05$ \\
\hline & Within groups & 1.86 & 33 & 0.056 & & \\
\hline & Total & 2.41 & 35 & & & \\
\hline \multirow[t]{3}{*}{$\mathrm{P}$} & Between groups & 1.38 & 2 & 0.689 & 70.236 & $<0.001$ \\
\hline & Within groups & 0.32 & 33 & 0.010 & & \\
\hline & Total & 1.70 & 35 & & & \\
\hline \multirow[t]{3}{*}{$\mathrm{Zn}$} & Between groups & 0.79 & 2 & 0.393 & 7.799 & $<0.01$ \\
\hline & Within groups & 1.66 & 33 & 0.050 & & \\
\hline & Total & 2.45 & 35 & & & \\
\hline
\end{tabular}


method, there is no need for such invasive sampling. The use of toad's toe bones was chosen because toe clipping was a commonly used standard method to identify individuals, particularly frogs and toads (McCarthy and Parris 2004). It is simple and safe and the toe clipped sample is applicable for genetics (Noonan and Gaucher 2006; St. Amour and Lesbarréres 2007), histological examinations (Kriger et al. 2006; Hyatt et al. 2007) or amphibian skeletochronological age determination (Bruce et al. 2002; Takashi and Masafumi 2009). Also, in most cases, toe clipping is an acceptable method which does not have any serious effects (Hartel and Nemes 2006). In summary, the elemental analysis of toe clipped bone samples have several advantages: there is no need to kill the animals, the analytical procedure has a small chemical reagent demand, and only a small amount of tissue is sufficient to make several kinds of laboratory analyses.

Our results demonstrated that anthropogenic effects cause differences in the elemental contents of $B$. bufo toe bones. Although physiological differences and morphological deformities were not found, the concentrations of the main elements in the bones were markedly lower at the urban pond than at the rural sites. We would like to stress that the elemental concentrations may be measured reliably by this method even in a small amount of toe bones. Thus, the developed technique based on toad toe bones may be useful for the assessment of contamination in pollution studies without killing the specimens of, usually legally protected, frog and toad species.

\section{References}

Blaustein, A. R., Romansic, J. M., Kiesecker, J. M., \& Hatch, A. C. (2003). Ultraviolet radiation, toxic chemicals, and amphibian population declines. Diversity and Distribution, 9, 123-140.

Bruce, R. C., Castanet, J., \& Francillon-Vieillot, H. (2002). Skeletochronological analysis of variation in age structure, body size, and life history in three species of Desmognathine salamanders. Herpetologica, 58, 181-193.

Demichellis, S. O., De Latorrei, F. R., Ferrari, L., Garcia, M. E., \& Salibiáni, A. (2001). Tadpoles assay: Its application to a water toxicity assessment of a polluted urban river. Environmental Monitoring and Assessment, 68, 63-73.

Fenoglio, C., Grosso, A., Boncompagni, E., Milanesi, G., Gandini, C., \& Barni, S. (2006). Morphofunctional evidence of changes in principal and mitochondria-rich cells in the epidermis of the frog Rana kl. esculenta living in a polluted habitat. Archives of Environmental Contamination and Toxicology, 51, 690-702.

Flyaks, N. L., \& Borkin, L. J. (2004). Morphological abnormalities and heavy metal concentrations in anurans of contaminated areas, eastern Ukraine. Applied Herpetology, 1, 229-264.

Green, E. D. (2001). Toe-clipping of frogs and toads. Amphibian Research and Monitoring Initative. Accessed 2004 from http://www.nwhc.usgs.gov/publications/ amphibian_research_procedures/toe_clipping.jsp.

Hartel, T., \& Nemes, S. (2006). Assessing the effect of toe clipping on yellow bellied toads. Acta Zoologica Academiae Scientiarum Hungaricae, 52, 359-366.

Hayes, T. B., Haston, K., Tsui, M., Hoang, A., Haeffele, C., \& Vonk, A. (2002). Feminization of male frogs in the wild. Nature, 419, 895-900.

Herkovits, J., \& Helguero, L. A. (1998). Copper toxicity and copper-zinc interactions in amphibian embryos. The Science of the Total Environment, 221, 1-10.

Hyatt, A. D., Boyle, D. G., Olsen, V., Boyle, D. B., Berger, L., Obendori, D., et al. (2007). Diagnostic assays and sampling protocols for the detection of Batrachochytrium dendrobatidis. Diseases of Aquatic Organisms, 73, 175-192.

Icochea, J., Quispitupac, E., Portilla, A., \& Ponce, E. (2002). Framework for assessment and monitoring of amphibians and reptiles in the Lower Urubamba Region, Peru. Environmental Monitoring and Assessment, 76, 55-67.

James, S. M., \& Little, E. E. (2003). The effects of chromic cadmium exposure on American toad (Bufo americanus). Environmental Toxicology and Chemistry, 22, 377-380.

Janus, A. M., Faryna, M., Haberko, K., Rakowska, A., \& Panz, T. (2008). Chemical and microstructural characterization of natural hydroxyapatite derived from pig bones. Microchimica Acta, 161, 349-353.

Johansson, M., Rasanen, K., \& Merila, J. (2001). Comparison of nitrate tolerance between different populations of the common frog, Rana temporaria. Aquatic Toxicology, 54, $1-14$.

Johnson, P. T. J., Lunde, K. B., Ritchie, E. G., \& Launer, A. E. (1999). The effect of trematode infection on amphibian limb development and survivorship. Science, 284, 802-804.

Klepinger, L. L. (1984). Nutritional assessment from bone. Annual Review of Anthropology, 13, 75-96.

Kriger, K. M., Hines, H. B., Hyatt, A. D., Boyle, D. G., \& Hero, J. M. (2006). Techniques for detecting chytridiomycosis on wild frogs: Comparing histology with real-time Taqman PCR. Diseases of Aquatic Organisms, 71, 141-148.

Loumbourdis, N. S., Kostaropoulos, I., Theodoropoulou, B., \& Kalmanti, D. (2007). Heavy metal accumulation and methallothionein concentration in the frog Rana ridibunda after exposure to chromium or a mixture of chromium and cadmium. Environmental Pollution, 145, 787-792.

McCarthy, M. A., \& Parris, K. M. (2004). Clarifying the effect of toe clipping on frogs with Bayesian statistics. Journal of Applied Ecology, 41, 780-786.

Mizgireuv, I. V., Flax, N. L., Borkin, L. J., \& Khudoley, V. V. (1984). Dysplastic lesions and abnormalities in amphibians associated with environmental conditions. Neoplasma, 31, $175-181$. 
Noonan, B. P., \& Gaucher, P. (2006). Refugial isolation and secondary contact in the dyeing poison frog Dendrobates tinctorius. Molecular Ecology, 15, 4425-4435.

Oudadesse, H., Martin, S., Derrien, A. C., Lucas-Girot, A., Cathelineau, G., \& Blondiau, G. (2004). Determination of $\mathrm{Ca}, \mathrm{P}, \mathrm{Sr}$ and $\mathrm{Mg}$ in the synthetic biomaterial aragonite by NAA. Journal of Radioanalytical and Nuclear Chemistry, 262, 479-483.

Pavel, J., \& Kucera, M. (1986). Cumulation of heavy metals in frog. Ekológia, 5, 431-440.

Perez-Coll, C. S., Herkovits, J., Fridman, O., Daniel, P., \& D'Eramo, J. L. (1997). Metallothioneins and cadmium uptake by the liver in Bufo arenarum. Environmental Pollution, 97, 311-315.

Puky, M., \& Oertel, N. (1997). On the protective role of maternal organism in amphibians. Opuscula Zoologica, 29-30, 125-132.

Rowe, C. L., Hopkins, W. A., \& Coffman, V. R. (2001). Failed recruitment of southern toads (Bufo terrestris) in a trace element-contaminated breeding habitat: Direct and indirect effects that may lead to a local population sink. Archives of Environmental Contamination and Toxicology, 40, 399-405.

Simon, E., Braun, M., \& Tóthmérész, B. (2010). Nondestructive method of frog (Rana esculenta L.) skeleton elemental analysis used during environmental assessment. Water, Air, and Soil Pollution, 209, 467-471.
Sparling, D. W., Linder, G., \& Bishop, C. A. (Eds.). (2000). Ecotoxicology of amphibians and reptiles. Pensacola, FL: Society of Environmental Toxicology and Chemistry (SETAC), p. 904.

St. Amour, V., \& Lesbarréres, D. (2007). Genetic evidence of Ranavirus in toe clips: An alternative to lethal sampling methods. Conservation Genetics, 8, 1247-1250.

Stolyar, O. B., Loumbourdis, N. S., Falfushinska, H. I., \& Romanchuk, L. D. (2008). Comparison of metal bioavailability in frogs from urban and rural sites of Western Ukraine. Archives of Environmental Contamination and Toxicology, 54, 107-113.

Takashi, M., \& Masafumi, M. (2009). The validity of skeletochronology in estimating ages of Japanese clouded salamanders, Hynobius nebulosus (Amphibia, Caudata). Current Herpetology, 28, 41-48.

Unrine, J. M., Hopkins, W. A., Romanek, C. S., \& Jackson, B. P. (2007). Bioaccumulation of trace elements in omnivorous amphibian larvae: Implications for amphibian health and contaminant transport. Environmental Pollution, 149, 182-192.

Welsh, H. H., \& Ollivier, L. M. (1998). Stream amphibians as indicators of ecosystem stress: A case study from California's redwoods. Ecological Applications, 8, 11181132.

Zar, J. H. (1996). Biostatistical analysis. New Jersey: Prentice Hall. 662 pp. 